\title{
Grey Zones of Resistance and Contemporary Political Theory
}

\author{
Maša Mrovlje and Jennet Kirkpatrick
}

'For a revolutionary work is not one that glorifies victories and conquests, but one that brings to light the Revolution's most painful conflicts'.

-Albert Camus, Lyrical and Critical Essays

Of late, resistance has become a central notion in political theory, standing at the heart of attempts to respond to the dilemmas of contemporary times. However, many accounts tend to ascribe to an idealised, heroic view. In this view, resistance represents a clearcut action against injustice and stems from individuals' conscious choice and their unwavering ethical commitment to the cause. Some liberal scholars, most notably Candice Delmas and Jason Brennan, have argued that citizens of democratic societies have a moral duty to resist state-sanctioned injustice. This resistance occurs either through 'principled - civil or uncivil - disobedience' or through 'defensive actions' (Delmas 2018: 5; Brennan 2019: 15). While acknowledging that pervasive injustice can compromise our cognitive and moral capacities, however, their articulation of our political obligation to resist refrains from a sustained examination of the moral dilemmas, uncertainties and risks that arise when fighting systemic oppression (Delmas 2018: 198-222; Brennan 2019: 28-59, 210-14).

Some post-Marxist scholars reveal a similar tendency. Michael Hardt and Antonio Negri have affirmed the potential of resistance by the multitude to subvert the global, all-pervasive biopolitical order of the Empire and institute 'absolute democracy' (Hardt and Negri 2004: 90-91). Nevertheless, they cast this promise of resistance within the moral binary of good and evil, where the uprising 
of the suffering, yet virtuous multitude will heroically overcome the villainous forces of oppression and bring about the realm of freedom. What remains unaccounted for are the contingencies, complex complicities and unpredictability entailed in collective action against the existing structures and hierarchies of power (Anker 2012: 142-47; Kirkpatrick 2019: 139-41). For all their insight, then, recent theories offer an incomplete picture of the inevitable ambiguities involved in resistance activity, risking to discredit less heroic practices of resistance and impoverish our imagination of the possibilities for oppositional politics (Mihai 2020: 2).

This special issue addresses this gap by inquiring into the grey zones of resistance - the morally ambiguous situations and tragic choices that resistance activists face. Its goal is to challenge the dominant notions of heroic resistance and to scrutinise the murky areas that lie in between unwavering idealism and ugly compromise, virtuous commitment and cowardly quiescence, unconditional solidarity and vile betrayal. From a heroic perspective, the murkiness of resistance can contribute to the lingering spectre of disenchantment. It can entrench scepticism over the possibilities of collective action and emancipatory societal transformation. In contrast, the contributions to this special issue embrace the anguish that, in Albert Camus's view, characterises any true 'revolutionary' work (Camus 1970: 208). They posit that enhancing our understanding of the grey zones within resistance represents an important resource for reinvigorating the politics of opposition and struggle in our uncertain political world shorn of traditional moral certitudes.

Several contemporary works have brushed up against the ambiguity of resistance but not explored it carefully or in detail. Social and political theorists have developed novel understandings of everyday, ordinary or disguised forms of resistance, and illuminated the political, resistant potential of withdrawal from political life (Vinthagen and Johansson 2013; Bayat 2000; Kirkpatrick 2017, 2011). Critical theorists have grounded visions of a better future in a careful engagement with past defeats, losses and failures as propitious sources for rethinking the forms of critique for the contemporary era (Winters 2016; Thaler 2019; McIvor 2016). Finally, scholars working in the field of political memory have exposed the troubling political implications of hegemonic myths of heroic resistance in societies transitioning from violent pasts, drawing attention 
to the ambivalences of political agency in circumstances of pervasive repression (Leebaw 2019; Mihai 2019a; Mrovlje 2017, 2020).

The special issue represents a timely rejoinder to this burgeoning body of scholarship because it targets heroic agency directly, revealing the fantasy of unified subjects of resistance who possess an unwavering virtuous commitment to the cause. To move beyond the binary opposition between principled defiance and the complacent acceptance of status quo, we argue, we need to make a shift that may be uncomfortable and disconcerting - that is, delving into the grey zones of resistance. This shift can be unwelcome because heroic myths of resistance often constitute an inextricable part of a community's collective identity, reproducing themselves across generations through emotionally anchored schemes of memorymaking (Mihai 2019a: 52). An inquiry into the ambiguities of resistance, in this respect, demands a willingness to entertain what is unsettling, disrupting our sense of who we are and exposing us to uncertainty and risk (Beausoleil 2017: 295).

Since Primo Levi's powerful formulation of the concept in the context of concentration camps, scholars have employed the grey zone discourse to shed light on the complexities of complicity in systemic injustice that evade clear-cut binaries between good and evil (Levi 2015: 2405-570; Leebaw 2011; Mihai 2019b). Situating resistance within the grey zones dispenses with the presumption of sovereign agency, that is, the notion that individuals act freely and are untrammelled by the weight of the world. Taking account of the grey zones shows that the 'right' course of resistance is not guaranteed. It cannot be ensured by a set of universal moral standards that binds individuals irrespective of their particular context or by the necessary or inevitable progress of history. Resisters are not epitomes of (often masculine) heroism, standing unfailingly on the side of moral good, absolutely committed to the cause and selflessly assuming the lives of hardship, risk and self-sacrifice. Within the grey zones, resistance poses difficult moral dilemmas that elude easy answers and trouble pre-given schemas of resolution. Resisters are pluralistic actors, shot through by a variety of interests and loyalties and shaped by a plethora of situational factors beyond their full control, including the hierarchies of gender, race and class inequality. Indeed, the moral dilemmas they confront can stem from their embeddedness within the same conditions of 
oppression that they seek to fight. Those who act within a web of overlapping, mutually constituting oppressions can face painful complicities, conflicting allegiances, and moral uncertainty. Their situations constitute the ineluctable horizons of resistant action and expose the complexities of agency, commitment and solidarity in conditions of pervasive oppression.

Delving into the grey zones of resistance, then, the special issue offers insight into resistance as an experiential, situational and ambiguous process of responding to the worldly field of oppressive structures. Its specific focus lies on interrogating the dynamics by which resistant practices become complicit with the existing conditions of systemic violence and the possibilities of resisting these dynamics. Given this focus, it is also particularly interested in the ways that the embodied, context-specific understanding characteristic of narratives - historical or fictional - can disclose the lived reality and ambiguity of resistance.

Bringing together perspectives from social and political theory, transitional justice, memory studies and art, the special issue explores the grey zones of resistance in a wide range of contexts. These include organised armed struggles against totalitarian, authoritarian and colonial regimes as well as everyday, piecemeal, passive and 'limit' varieties of defiance against or non-compliance with patterns of systemic injustice. While each article reveals the limits of heroic myths of resistance, it does so from a range of vantage points. Among the topics addressed are the moral dilemmas of revolutionary violence in conditions of radical inequality, the complexities of betrayal in resistance movements, the compromises and complicities entailed in subversive action, and the ambivalences of moral goodness in evil times. Further, the articles illuminate these experiential dilemmas through a wide range of source material, including novels, radio broadcasting programmes, and victim testimonies. To illustrate and nuance their theoretical findings, finally, the contributors draw on an array of practical examples of the grey zones of resistance from different historical periods and geographical regions. These examples range from the French Resistance during World War II to the anti-apartheid struggle in South Africa and the war in Bosnia and Herzegovina.

Tal Correm explores the ambivalent role of violence in liberation struggles by staging a mutually enriching dialogue between Hannah Arendt and Frantz Fanon on the relation between violence and 
political freedom. Against the conventional interpretations of the two thinkers, the paper challenges the binary distinction between justifiable resistance that allows for only short-term, instrumental use of violence, and dubious resistance where violence is intrinsically justified as a creative, organic life-force of the oppressed. Instead, it discusses the constitutive role of violence as a condition of possibility of politics, highlighting the impossibility of separating the bloody moments of revolution from the constitution of the political community as a space of public freedom. Correm's paper thus not only offers innovative readings of the two most prominent twentiethcentury theorists thinking the relation between violence and politics but also presents a fresh perspective on the justifiability and costs of resistance violence in circumstances of radical inequality.

Maša Mrovlje, in turn, challenges the hegemonic masculinist myths of resisters' heroism and absolute commitment by inquiring into the thorny issue of betrayal. Specifically, she is interested in exposing and contesting the gendered representation of betrayal in resistance movements. For a theoretical framework, the paper draws on Simone de Beauvoir's critique of masculinist myths of femininity in The Second Sex, combined with contemporary feminist scholarship on the oppressive constructions of female subjectivity in debates on war and violence. It traces how the hegemonic visions of virile resistance tend to subsume the ambiguities of women's resistance experiences under two reductive myths of femininity - the self-sacrificial mother and the seductive femme fatale - while obscuring the complexities of betrayal arising from women's embodied vulnerabilities. The paper illustrates the political relevance of this theoretical exploration on the example of two representative French Resistance novels, Joseph Kessel's Army of Shadows and Roger Vailland's Playing with Fire. By deconstructing naturalised representations of women resisters, Mrovlje argues, we can unearth the oppressive implications of hegemonic visions of heroic resistance and challenge the insidious processes that perpetuate hierarchies of gender inequality post-liberation.

Gisli Vogler shifts the focus from organised, collective armed struggles to everyday, often invisible and tentative, acts of resistance to systemic repression. In particular, he interrogates the grey zones of subversion as a practice of resistance from within 
relations of domination. Drawing on the example of subversive acts in radio broadcasting, Vogler creatively engages Frantz Fanon's influential work on the resistant potential of radio, enriching it with insights into the everyday, multi-faceted character of subversive politics. His paper approaches subversion in its lived, embodied reality to challenge the untenable myths of heroic agency and to reveal the dynamic ways in which complicity and betrayal constitute the horizon within which subversive acts can become a highly effectual, if impure, form of resistance. To illustrate the ambiguity of subversion, Vogler turns to the case study of Radio Bantu in South Africa, highlighting the disguised practices of resistance in broadcasting that subverted the dominant ideology of the apartheid regime. By cross-pollinating theoretical and practical insights into the ambiguities of subversion, his paper offers a context-sensitive understanding of the emancipatory potentials of subversion as part of a more extensive arsenal of resistant practices.

Bronwyn Leebaw concludes the special issue by reflecting on the double-edged character of telling stories about the grey zones of resistance. Drawing on Hannah Arendt and Svetlana Broz, two exemplary storytellers in dark times, Leebaw defends the value of recovering memories of resistance as exemplars of political agency and responsibility. Yet she also warns of the potentially pernicious power of exemplars, showing how they may silence those who do not act in the way that conforms to our ideals of exemplary resistance. For instance, Arendt was suspicious of appeals to goodness, claiming they are ill-suited to challenge systematic forms of atrocity. Her identification of 'good' exemplars with public actions, however also risks obscuring the structural logics of abuse that are often predicated upon arbitrarily stigmatising some concerns as 'merely' private. In contrast, Broz's efforts to gather stories of political violence among the survivors of the war in Bosnia and Herzegovina refused to naturalise the binary between the 'good' and 'bad' exemplars of resistance. Instead, she illuminated the political implications of private acts of goodness, rescue and care, thus revealing the neglected possibilities of agency, as well as how relations of care can be exploited to coerce people into complicity. 


\section{Acknowledgements}

We warmly thank the two anonymous reviewers for their attentive reading and excellent comments. Special thanks are also due to the editors of Theoria for their insights on this special issue. We are incredibly grateful to the contributors for their rich, compelling and thought-provoking articles. Several contributors presented their work at a panel on 'Grey Zones of Resistance and Contemporary Political Theory', which took place at the 2019 American Political Science Association Annual Meeting in Washington, DC. Maša Mrovlje organised the panel, and Jennet Kirkpatrick acted as discussant. We are grateful to all participants for their encouraging questions and recommendations.

MAŠA MROVLJE is a postdoctoral fellow at the Institute for Advanced Studies in the Humanities, University of Edinburgh. Her research interests are located within contemporary political theory, with a focus on theories of resistance and resistance movements. She is author of Rethinking Political Judgement: Arendt and Existentialism (Edinburgh University Press, 2019). Her articles have appeared in Philosophia, Law, Culture and the Humanities, The European Legacy and Political Theory. E-mail: masa.mrovlje@ed.ac.uk

Jennet KirkPatrick is Associate Professor in the School of Politics and Global Studies at Arizona State University. Her work, which focuses on resistance, includes Uncivil Disobedience: Studies in Violence and Democratic Politics (Princeton University Press) and The Virtues of Exit: On Resistance and Quitting Politics (University of North Carolina Press). E-mail: jennetk@asu.edu

\section{References}

Anker, E. 2012. 'Left Melodrama', Contemporary Political Theory 11 (2): 13052. https://doi.org/10.1057/cpt.2011.10.

Bayat, A. 2000. 'From "Dangerous Classes" to "Quiet Rebels": Politics of the Urban Subaltern in the Global South', International Sociology 15 (3): 53357. https://doi.org/10.1177/026858000015003005. 
Beausoleil, E. 2017. 'Responsibility as Responsiveness: Enacting a Dispositional Ethics of Encounter', Political Theory 45 (3): 291-318. https:// doi.org/10.1177/0090591716 651109.

Brennan, J. 2019. When All Else Fails: The Ethics of Resistance to State Injustice. Princeton: Princeton University Press.

Camus, A. 1970. Lyrical and Critical Essays. New York: Vintage Books.

Delmas, C. 2018. A Duty to Resist: When Disobedience Should Be Uncivil. New York: Oxford University Press.

Hardt, M. and A. Negri. 2004. Multitude: War and Democracy in the Age of Empire. New York: The Penguin Press.

Kirkpatrick, J. 2011. 'The Prudent Dissident: Unheroic Resistance in Sophocles' Antigone', Review of Politics 73 (3): 401-24. http://dx.doi.org.ezproxy.is.ed. ac.uk/10.1017/S0034 670511003421.

Kirkpatrick, J. 2017. The Virtues of Exit: On Resistance and Quitting Politics. Chapel Hill, NC: University of North Carolina Press.

Kirkpatrick, J. 2019. 'Resistant Exit', Contemporary Political Theory 18 (2): 135-57. https://doi.org/10.1057/s41296-018-0252-1.

Leebaw, B. 2011. Judging State-Sponsored Violence, Imagining Political Change. Cambridge: Cambridge University Press.

Leebaw, B. 2019. 'If Only More Such Stories Could Have Been Told: Ways of Remembering Resistance', Law, Culture and the Humanities 15 (2): 448-76. https://doi.org/10.1177/1743872115599714.

Levi, P. 2015. The Complete Works of Primo Levi. London: Penguin Classics.

McIvor, D. W. 2016. Mourning in America: Race and the Politics of Loss. Ithaca, NY: Cornell University Press.

Mihai, M. 2019a. 'The "Affairs” of Political Memory', Angelaki 24 (4): 52-69. https://doi.org/10.1080/0969725X.2019.1635825.

Mihai, M. 2019b. 'Understanding Complicity: Memory, Hope and the Imagination', Critical Review of International Social and Political Philosophy 22 (5): 504-22. https://doi.org/10.1080/13698230.2019.1565692.

Mihai, M. 2020. 'The Hero's Silences: Vulnerability, Complicity, Ambivalence', Critical Review of International Social and Political Philosophy, published online: 21 July, 1-22. https://doi.org/10.1080/1369823 0.2020 .1796332 .

Mrovlje, M. 2017. ‘Judging Violent Resistances: Camus's Artistic Sensibility and the Grey Zone of Rebellion', Law, Culture and the Humanities published online: 14 July, 1-20. https://doi.org/10.1177/1743872117721421.

Mrovlje, M. 2020. 'The Political Value of Disappointment among Ex-Resistance Fighters: Confronting the Grey Zone of Founding', Political Theory 48 (3): 303-29. https://doi.org/10.1177/0090591719880626.

Thaler, M. 2019. 'Bleak Dreams, Not Nightmares: Critical Dystopias and the Necessity of Melancholic Hope', Constellations 26 (4): 607-22. https://doi. org/10.1111/1467-8675.12401. 
Vinthagen, S. and A. Johansson. 2013. “"Everyday Resistance:” Exploration of a Concept and Its Theories', Resistance Studies Magazine 1: 1-46.

Winters, J. R. 2016. Hope Draped in Black: Race, Melancholy and the Agony of Progress. Durham: Duke University Press. 